Al Maqayis : Jurnal Pendidikan Bahasa Arab dan Kebahasaaraban

Vol. 8 No. 2, December 2021, 198-219

p-ISSN 2338-133X e-ISSN 2615-3890

doi: https://dx.doi.org/10.18592/jams.v8i2.4901

Submit: 14/07/2021 Review: 16/11/2021 Publish: 02/12/2021

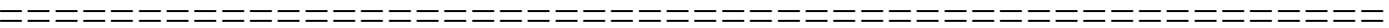

The Effectiveness of Arabic Contextual Teaching and Learning

(CTL) Strategy

\title{
Efektifitas Strategy Contextual Teaching and Learning (CTL) Bahasa Arab
}

\author{
Mira Zulistia \\ Sanggar Kegiatan Belajar (SKB) Kota Banjarbaru, Kalimantan Selatan, Indonesia \\ Corresponding E-mail: mirazulistia@gmail.com
}

\begin{abstract}
:
This study aims to determine the process of using the CTL (contextual teaching and learning) strategy in learning Arabic speaking skills at MA Manbaul Ulum, and to determine the effectiveness of learning Arabic using the CTL strategy in improving speaking skills at MA Manbaul Ulum. From the research results, it was found that there was a comparison between the pretest experimental class and the control class, in the test $(t)$ the sig value of 0.183 was greater than $0.05(0.183>0.05)$. So there is no difference in ability between the experimental class and the control class before using CTL or the initial ability of the experimental and control class is the same. Then the results of the comparison between the experimental and control class posttest, in the test $(\mathrm{t})$ the sig 0.011 value is smaller than $0.05(0.011<0.05)$. So there is a difference in the results of the study between the experimental class that uses CTL and the control class that does not use CTL to improve speaking skills at MA Manbaul Ulum. It can be concluded that the use of the CTL strategy to improve kalam skills at MA Manbaul Ulum is said to be effective.
\end{abstract}

Keywords: Contextual teaching and learning, speaking skill, learning Arabic 


\section{Al Maqayis Jurnal Pendidikan Bahasa Arab dan Kebahasaaraban, 8 (2), 2021 p-ISSN 2338-133X e-ISSN 2615-3890}

\section{Pendahuluan}

Pendidikan adalah usaha sadar dan terencana untukmewujudkan suasana belajar dan proses pembelajaran untuk peserta didik secara aktif, mengembangkan potensi dirinya untuk memiliki kekuatan spiritual keagamaan, pengendalian diri, kepribadian, kecerdasan akhlak mulia serta keterampilan yang diperlukan dirinya dan masyarakat. Pendidikan bertujuan untuk mencapai taraf hidup atau kemajuan lebih baik serta pendidikan merupakan proses begi peserta didik untuk mengerti, paham, dan membuat manusia lebih kritis dalam berpikir. ${ }^{1}$ Pendidikan saat ini yang berorientasi pada hasil akhir siswa, menyebabkan pendidikan hanya berfokus pada sesuatu yang dapat diukur melalui niali-nilai. Siswa dianggap berhasil dalam pelajaran apabila mendapatkan nilai yang tinggi., padahal adanya nilai yang tinggi bukan merupakan tujuan utama dalam proses pendidikan. Hal yang menjadi orientasi pendidikan yaitu proses pembelajaran yang bermakna bagi siswaBeberapa siswa belum menyadari makna yang didapat dari ${ }^{2}$ pembelajaran untuk diterapkan dalam kehidupan sehari-hari. Mereka hanya memandang pengetahuan sebagai sesuatu yang harus dihafalkan. ${ }^{3}$

Proses pembelajaran merupakan upaya membimbing siswa untuk memproleh pembelajaran yang bermakna sesuai tujuan pembelajaran yang diharapkan. Proses pembelajaran adanya interaksi dan komunikasi timbal balik antara guru dan siswa. Dalam proses pembelajaran guru dan siswa merupakan komponen penting dan tidak dapat dipisahkan. Adanyan interaksi dan komunikasi yang menunjang antara guru dan siswa untuk mencapai tujuan pembelajaran secara optimal sehingga meningkatkan

1 Maulana Ismail Sardi, Imran Akhmad, and Sanusi Hasibuan, "PERBEDAAN STRATEGI PEMBELAJARAN TERHADAP MOTIVASI DAN HASIL BELAJAR PASSING ATAS BOLA VOLI PADA SISWA KELAS XI SMA," Jurnal Pedagogik Olahraga 7, no. 1 (n.d.): 19-24.

2 Nyoman Ayu Putri Lestari, "Pengaruh Implementasi Pembelajaran Kontekstual Terhadap Hasil Belajar Matematika Dengan Kovariabel Kemampuan Numerik Dan Kemampuan Verbal," Jurnal Pendidikean Dasar Nusantara 5, no. 1 (2019): 72-87.

${ }^{3}$ Ni Wayan Sri Parwasih and Zusje WM Warouw, "Pengaruh Model Pembelajaran Contextual Teaching and Learning (CTL) Terhadap Hasil Belajar Siswa Pada Pembelajaran IPA Materi Sistem Pencernaan Manusia," SCIENING: Science Learning Journal 1, no. 1 (2020): 6-10. 


\section{Al Maqayis Jurnal Pendidikan Bahasa Arab dan Kebahasaaraban, 8 (2), 2021}

p-ISSN 2338-133X e-ISSN 2615-3890

kualitas pendidikan. Pembelajaran merupakan suatu kegiatan yang melibatkan 4 seeorang dalam upaya memperoleh pengetahuan, keterampilan dan nilai- nilai positif dan memanfaatkan serbagai sumber untuk belajar. Pembelajaran dapat melibatkan dua pihak yaitu siswa sebagai pelajar dan guru sebagai fasilitator, yang terpenting dalam kegiatan pembelajaran adalah terjadinya proses belajar (Rohani, R. 2019). Sedangkan menurut Mursid (2015) menyatakan bahwa Pembelajaran merupakan suatu kegiatan melaksanakan kurikulum suatu lembaga pendidikan agar dapat memengaruhi para siswa mencapai tujuan pendidikan yang telah ditetapkan. ${ }^{5}$

Salah satu faktor pendidikan yang perlu di perhatikan yaitu bagaimana proses pembelajaran dan siapa yang mengajarkan. Pembelajaran tidak hanya melibatkan kognisi akan tetapi juga mempengaruhi sikap, minat dan penggunaan strategi pembelajaran (Alsop et al.2005, Pintrich et al.1993). Pembelajaran yang ideal adalah proses yang terdapat interaksi dan komunikasi antara guru dan siswa untuk mencapai tujuan pembelajaran (Susilaningsih et.al. 2019). Dalam proses belajar mengajar guru sangat berpengaruh dalam memotivasi siswa (Fletcher et. al, 2011, Mc Clure et.al.2011, Spiller 2012), dengan hubungan siswa- guru dianggap penting untuk prestasi siswa (Tait et.al. 2018). Guru merupakan faktor utama dalam membentuk lingkungan belajar dan tugas utamanya adalah untuk memotivasi siswa untuk belajar (Hornstra et.al. 2015). ${ }^{6}$ Guru professional berusaha melaksanakan proses pembelajaran dengan menerapkan strategi pembelajaran yang berbeda. Strategi pembelajaran yang sesuai dengan karakteristik mata pelajaran dan kepribadian siswa akan mampu mendorong tercapainya tujuan pembelajaran secara optimal. Adanya strategi pembelajaran yang digunakan guru, siswa diharapkan aktif terlibat dalam proses pembelajaran dan belajar dari teman melalui kerja

4 Andika Maja, "Peningkatan Keterampilan Berbicara Siswa Menggunakan Pendekatan Pembelajaran Kontekstual Berbantuan Media Gambar Di Sekolah Dasar," Jurnal Pendidikan dan Pembelajaran Khatulistiwa 6, no. 3 (n.d.).

5 Anita Husnawati et al., "Strategi Pembelajaran Anak Usia Dini Pada Masa Pandemi Covid-19," 2021, 29-36.

${ }^{6}$ Damar Septian et al., "Respon Dan Pengaruh Pendekatan Contextual Teaching Learning Terhadap Hasil Belajar IPA Materi Perubahan Sifat Benda Pada Siswa Kelas V Sekolah Dasar," Jurnal Pendidikan Fisika dan Sains (JPFS) 4, no. 1 (2021): 32-38. 


\section{Al Maqayis Jurnal Pendidikan Bahasa Arab dan Kebahasaaraban, 8 (2), 2021}

p-ISSN 2338-133X e-ISSN 2615-3890

kelompok, diskusi, saling mengoreksi selain itu peserta didik juga sebagai penerima dan belajar secara individual. Pembelajaran yang berorientasi pada penguasaan materi dianggap gagal menghasilkan siswa yang aktif, kreatif, dan inovatif. Peserta didi berhasil mengingat jangka pendek, tetapi gagal membekali siswa memecahkan persoalan dalam kehidupan jangka panjang. Oleh karena itu, perlu adanya perubahan strategi pembelajaran yang lebih bermakna sehingga dapat membekali siswa dalam menghadapi permasalahan hidup yang dihadapi sekarang maupun yang akan datang. ${ }^{7}$

Adapun permasalah pendidikan saat ini yaitu dalam hal proses pembelajaran. Proses pembelajaran tidak mampu mendorong siswa untuk mengembangkan kemampuan berpikirnya. Guru hanya menyuruh siswa memahami materi pelajaran untuk dipahami saja tanpa adanya penerapan pembelajaran dalam kehidupan sehari-hari dari materi yang di ajarkan. ${ }^{8}$

Pembelajaran keterampilan berbahasa bertujuan untuk menumbuhkan dan mengembangkan keterampilan siswa. Keterampilan berbahasa mempunyai empat komponen yaitu : keterampilan mendengar, keterampilan berbicara, keterampilan membaca dan keterampilan menulis.Keterampilan berbicara sebagai salah satu dari ${ }^{9}$ empat keterampilan memiliki peranan penting dalam komunikasi. Keterampilan berbicara merupakan keterampilan bahasa berupa penyampaian informasi secara lisan. Berbicara yakni menyampaikan suatu gagasan atau pesan guna mempermudah orang dalam memahami informasi yang disampaikan orang lain sehingga komunikasi dapat berjalan dengan lancar. Berbicara merupakan alat dalam berkomunikasi, yang diharapkan keterampilan berbicara menjadi interaktif aktif dua arah. Sehingga

7 S Ag Fadhilah, "Penerapan Metode Contextual Teaching Learning Dalam Pembelajaran Ilmu Nahu Di MAN 2 Bireuen” (n.d.).

8 Erawati Erni, Muhammad Yunus, and Muhammad Nur, "Pengaruh Model Pembelajaran Contextual Teaching Learning (CTL) Terhadap Hasil Belajar IPS Siswa SD," Bosowa Journal of Education 1, no. 1 (2020): 16-23.

9 Sakdiah Wati, "KEEFEKTIFAN PENDEKATAN KONTEKSTUAL (CONTEXTUAL TEACHING AND LEARNING) DALAM PEMBELAJARAN MENULIS PUISI SISWA SMP," Jurnal Bindo Sastra 3, no. 1 (2019): 55-62. 


\section{Al Maqayis Jurnal Pendidikan Bahasa Arab dan Kebahasaaraban, 8 (2), 2021}

p-ISSN 2338-133X e-ISSN 2615-3890

pembelajaran keterampilan berbicara bukan lagi hal monoton akan tetapi adanya respon dari pendengar. ${ }^{10}$

Keterampilan berbicara merupakan keterampilan yang perlu dikuasai denga baik. Keterampilan ini merupakan indikator terpenting kebarhasilan siswa. Dengan penguasaaan keterampilan berbicara yang baik, siswa dapat mengkomunikasikan ide-ide, pendapat dan gagasannnya. Keterampilan berbicara berkaitan erat dengan tata bahasa, kosa katam keterampilan mendengar, dll.Menurut Ismawati (2012:49) bahwa 11 keterampian berbicara adalah salah satu keterampilan berbahasa sebagai kemampuan mengucapkan bunyi- bunyi artikulasi atau kata-kata untuk megekspresikan, menyatakan serta mengungkapkan pendapat atau pikiran dan perasaan kepada seseorang atau kelompok secara lisan, baik secara berhadapan ataupun dengan jarak jauh. Berbicara adalah kegiatan menyampaikan pesan melalui bahasa lisan. Dalam Resmini (2007:1) bahwa berbicara menurut Deprtemen Pendidikan dan Kebudayaan diartikan suatu penyampaian maksud (ide, pikiran, isi hati) seseorang kepada orang lain dengan menggunakan bahasa lisan sehingga maksud tersebut dapat dipahami oleh orang lain. ${ }^{12}$

Kesulitan siswa dalam keterampilan berbicara sebagian besar disebabkan oleh guru yang biasanya menggunakan metode tradisional dalam proses belajar mengajar. Metode yang kurang efektif menyebabkan siswa bosan dan memerlukan banyak waktu untuk dapat berbicara terutama dalam melakukan percakapan atau komunikasi. Bericara merupakan komponen penting dalam pengajaran bahasa Arab dan keterampilan yang penting dalam berkomunikasi dengan bahasa Arab.Semakin banyak kita berlatih 13

${ }^{10}$ I Made Gatra, "Meningkatkan Keterampilan Berbicara Siswa SMA Dwijendra Gianyar Melalui Model Pembelajaran Contextual Teaching And Learning," Journal of Education Action Research 2, no. 4 (2018): 322-330.

${ }^{11}$ Imelda Imelda, Gazali Gazali, and Efendi Efendi, "Meningkatkan Keterampilan Berbicara Siswa Kelas VI SD Inpres Kantewu Melalui Pendekatan Contextual Teaching And Learning (CTL)," Jurnal Kreatif Online 6, no. 2 (n.d.).

12 Tati Nurhayati, Rini Herminastiti, and Nor Khakim, "Upaya Meningkatkan Keterampilan Berbicara Melalui Metode Contextual Teaching and Learning Dalam Kegiatan Circle Time," 2019.

13 Saiful Mustofa, “تأثثير استخدام وسيلة التعليم" لعبة دمية الأصابع" لترقية مهارة الكلام," Arabia 9, no. 2 (2019). 


\section{Al Maqayis Jurnal Pendidikan Bahasa Arab dan Kebahasaaraban, 8 (2), 2021 p-ISSN 2338-133X e-ISSN 2615-3890}

berbicara maka akan semakin terampil. Tidak ada proses yang instan tanpa melalui proses latihan. Ketrampilan berbicara akan memudahkan siapa saja untuk menyampaikan pemikiran secara sistematis dan teratur. Sehingga komunikasi lebih mudah karena apa yang disampaikan lebih mudah dipahami oleh pendengar. Hal ini menunjukkan bahwa laihan berbicara yang intensif dapat meningkatkan keterampilan berbicara dan seseorang tidak akan langsung terampil berbicara jika tidak melakukan latihan Kundharu Saddhono dan Slamet (2012).

Dalam meningkakan ketrampilan berbicara siswa maka diperlukan proses pembelajaran yang beragam sesuai dengan orientasi pendidikan yang diciptakan. Pada kegiatan pendidikan dalam sistem tradisional, kemampuan berbicara siswa relatif terhambat, sehingga masih banyak siswa yang belum mempunyai ketrampilan berbicara yang baik.Dengan kondisi ini maka harus ada perubahan strategi yang dilakukan oleh guru dalam meningkatkan kemampuan berbicara siswa. Perubahan ini di harapkan dapat membantu siswa dalam melaksanakan proses pembelajaran. Selain itu, upaya yang tepat dapat meningkatkan kemampuan keterampilan siswa dan meningkatkan prestasi siswa. ${ }^{14}$

Kemp (1995) menjelaskan bahwa strategi pembelajaran adalah suatu kegiatan pembelajaran yang harus dikerjakan guru dan peserta didik agar tujuan pembelajaran dapat dicapai secara efektif dan efisien. Kozma (dalam Sanjaya 2007) secara umum menjelaskan bahwa strategi pembelajaran dapat diartikan sebagai setiap kegiatan yang dipilih, yaitu yang dapat memberikan fasilitas atau bantuan kepada peserta didik menuju tercapainya tujuan pembelajaran tertentu. Dapat disimpulkan bahwa strategi itu merupakan kegiatan yang dilaksanan oleh guru dan siswa untuk mencapai tujuan pembelajaran. Salah satu strategi yaitu contextual teaching and learning (CTL). ${ }^{15}$

Menurut Johnson (2010: 35) pembelajaran contextual teaching and learning (CTL) adalah pembelajaran yang melibatkan siswa dalam kegiatan yang membantu

\footnotetext{
${ }^{14}$ Putu Intan Kurnia, "Meningkatkan Keterampilan Berbicara Menggunakan Metode Contextual Teaching and Learning Siswa Kelas XI SMK BSI," Jurnal Ilmu Sosial, Manajemen, Akuntansi dan Bisnis 1, no. 1 (2020): 14-23.

15 Sri Hidayati, "Strategi Pembelajaran Anak Usia Dini”" (2021).
} 


\section{Al Maqayis Jurnal Pendidikan Bahasa Arab dan Kebahasaaraban, 8 (2), 2021}

p-ISSN 2338-133X e-ISSN 2615-3890

menghubungkan pelajaran dengan konteks kehidupan siswa sehari-hari.Menurut 16 Sanjaya (2006: 109) mengemukakan bahwa strategi contextual teaching and learning (CTL) adalah strategi yang menekankan pada proses partisipasi siswa secara utuh, untuk dapat memahami materi yang dipelajari dan mengaitkannya dengan siruasi kehidupan nyata, sehingga mendorong siswa mampu untuk menerapkannya salam kehidupan. (CTL) adalah Menurut Nurhadi (Muslich, 2009), contextual teaching and learning ${ }^{17}$ konsep pendidikan yang membantu guru menghubungkan materi pembelajaran dengan situasi dunia nyata siswa, dan mendorong siswa untuk membuat hubungan antara pengetahuan mereka dan menerapkannya dalam kehidupan sehari-hari.Trianto 18 (2010:107) menambahkan pembelajaran contextual teaching and learning (CTL) menyajikan suatu pembelajaran yang mengaitkan materi pelajaran yang dipelajari siswa dengan konteks dimana materi pelajaran yang dipelajari siswa dengan konteks (relevansi dan manfaat) dimana materi tersebut digunakan, serta berhubungan dengan bagaimana seseorang belajar atau gaya belajar siswa. Pembelajaran kontekstual berfokus pada multi aspek lingkungan belajar.'Thobroni (2012:7) juga berpendapat bahwa pembelajaran 19 kontekstual yang merupakan salah satu pendekatan pembelajaran yang menekankan pentingnya lingkungan alamiah itu diciptakan dalam proses belajar agar kelas lebih "hidup" dan lebih "bermakna" karena siswa mengalami sendiri apa yang dipelajarinya.

Startegi Contextual Teaching and Learning (CTL) adalah pembelajaran yang dimulai dengan sajian atau tanya jawab lisan (ramah, terbuka, negosiasi) yang terkait dengan dunia siswa (daily life modeling), sehingga akan terasa manfaat dari materi yang

16 Ziaulhaq Siregar, "PENINGKATAN KEMAMPUAN PEMECAHAN MASALAH DAN SIKAP POSITIF MATEMATIS SISWA SMP NEGERI 4 PANTAI LABUMELALUI PENDEKATAN KONTEKSTUAL” (2018).

${ }^{17}$ Haslinda Haslinda, "KONSTRUKSI PENDEKATAN PEMBELAJARAN KONTEKSTUAL (CONTEXSTUAL TEACHING AND LEARNING) DALAM PENGAJARAN BAHASA (SUATU TINJAUAN EVALUASI)," vol. 1, 2018.

18 Wa Malmia et al., "Efektifitas Pembelajaran Contextual Teaching and Learning (Ctl) Terhadap Hasil Belajar Matematika Siswa:(The Effectiveness of Contextual Teaching and Learning (Ctl) on Student Mathematics Learning Achievements)," Uniqbu Journal of Exact Sciences 1, no. 2 (2020): 31-39.

${ }^{19}$ Ni Putu Yogiswari, Ni Ketut Suarni, and I Wayan Suastra, "Pengaruh Pendekatan Pembelajaran Kontekstual Berbasis Multiple Intelligences Gardner Terhadap Minat Dan Hasil Belajar IPA,” Jurnal Pendidikan dan Pembelajaran IP A Indonesia 9, no. 3 (2019): 112-121. 


\section{Al Maqayis Jurnal Pendidikan Bahasa Arab dan Kebahasaaraban, 8 (2), 2021}

p-ISSN 2338-133X e-ISSN 2615-3890

disajikan, motivasi belajar siswa akan muncul, dunia pemikiran siswa akan konkret, dan suasana menjadi kondusif, nyaman dan menyenangkan. ${ }^{20}$

Bila pembelajaran kontekstual diterapkan dengan benar, diharapkan siswa akan terlatih untuk dapat menghubungkan apa yang diperoleh dikelas dengan kehidupan nyata yang ada di lingkungannya. Siswa tidak hanya bertambah pengetahuan saja, tetapi juga sampai pada penerapan pengetahuan yang di dapatkannya melalui pembelajaran kontekstual. Tugas guru dalam kelas kontekstual adalah membantu siswa mencapai tujuan pembelajaran. ${ }^{21}$

Pembelajaran contextual teaching and learning (CTl) mengharapkan siswa tidak hanya memahami materi yang dipelajarinya, tetapi juga bagaimana materi tersebut dapat diterapkan dalam kehidupan sehari-hari yang bermanfaat bagi masyarakat. Belajar yang berorientasi guru-ke-siswa, siswa akan mampu mengembangkan pengetahuan dan keterampilan yang sesuai yang diperoleh untuk memecahkan masalah yang belum pernah kita temui sebelumnya. Dengan demikian, proses pembelajaran lebih mudah. ${ }^{22}$

Contextual teaching and learning (CTL) memiliki tujuh komponen yaitu: kontruktivistik (contructivism), bertanya (questioning), menemukan (inquiry), masyarakat belajar (learning community), pemodelan (modeling), Refleksi (Reflection), dan penilaian autentik (authentic assessment). Oleh karena itu, dengan menggunakan 23 contextual teaching and learning (CTL) dapat membantu siswa untuk menghubungkan pelajaran dengan situasi nyata. Dengan kata lain, metode ini dianggap sebagai metode pembelajaran keterampilan berbicara yang paling efektif. Dalam teori pengajaran

${ }^{20}$ RAHAYU SEPTYA, "PENERAPAN PENDEKATAN CONTEXTUAL TEACHING AND LEARNING (CTL) DALAM PEMBELAJARAN TEMATIK KELAS 1 SD NEGERI 02 MERGAWATI, KECAMATAN KROYA CILACAP” (2021).

21 Ahmad Nasirudin, Intan Rahmawati, and Suyitno Suyitno, "KEEFEKTIFAN MODEL CONTEXTUAL TEACHING AND LEARNING (CTL) TERHADAP HASIL BELAJAR MATEMATIKA MATERI PECAHAN," Journal for Lesson and Learning Studies 2, no. 2 (2019): 150-159.

22 Adi Gunawan, Hariyono Hariyono, and Ari Sapto, "Perbedaan Hasil Belajar Ilmu Pengetahuan Sosial Dengan Pendekatan Kontekstual Berbasis Budaya Lokal Di Madura," Jurnal Pendidikan: Teori, Penelitian, dan Pengembangan 2, no. 6 (2017): 867-873.

23 I Putu Adi Kasuma, MG Rini Kristiantari, and Ni Nyoman Ganing, "PENGARUH PENDEKATAN CONTEXTUAL TEACHING AND LEARNING (CTL) TERHADAP HASIL BELAJAR BAHASA INDONESIA SISWA,” MIMBAR PGSD Undiksha 5, no. 2 (2017). 


\section{Al Maqayis Jurnal Pendidikan Bahasa Arab dan Kebahasaaraban, 8 (2), 2021}

p-ISSN 2338-133X e-ISSN 2615-3890

pembelajaran, metode ini didasarkan pada ideologi konstruktivis yaitu siswa membangun pengetahuan mereka sendiri dengan mengeksplorasi ide-ide mereka berdasarkan pengetahuan dan pengalaman sebelumnya, menerapkan ide-ide ini ke situasi baru, dan mengintegrasikan pengetahuan baru yang diperoleh dengan pengetahuan sebelumnya" ( Wijarwadi: 2008). ${ }^{24}$

Kelebihan strategi pembelajaran kontekstual (CTL) yaitu: (1) Pembelajaran menjadi lebih bermakna dan berwawasan luas. Artinya siswa dituntut untuk menangkap hubungan antara pengalaman belajar di sekolah dengan kehidupan nyata. Hal ini sangat penting, karena melalui kemampuan mengaitkan yang ditemukan dengan materi kehidupan nyata, siswa tidak hanya akan mengerti materi dengan benar, tetapi materi yang dipelajari akan tertanam kuat dalam ingatan siswa, sehingga tidak mudah dilupakan. - (2) Pembelajaran lebih produktif dan mampu tumbuh diperkuat dengan konsep siswa karena pembelajaran kontekstual Pembelajaran mengikuti aliran konstruktivis dimana siswa menemukan sendiri pengetahuannya. Melalui pemebelajaran contextual teaching and learning (CTL) siswa diharapkan belajar melalui 'mengalami' bukan 'menghafal'. dalam proses) Memberikan kesempatan pada siswa untuk terlibat aktif (3 pembelajaran, (4) Siswa dapat berpikir kritis dan kreatif dalam mengumpulkan data, memahami suatu isu dan memecahkan masalah dan guru dapat lebih kreatif, (5) Siswa memahami apa yang mereka pelajari, (6) Pemilihan informasi berdasarkan kebutuhan siswa tidak ditentukan oleh guru, (7) Pembelajaran lebih menyenangkan dan tidak membosankan, (8) Membantu siswa bekerja dengan efektif dalam kelompok, (9) Terbentuk sikap kerja sama yang baik antar individu maupun kelompok.(Fankah, Ahmad.2015). ${ }^{26}$

24 Murti Bandung, "THE EFFECTIVENESS OF CONTEXTUAL TEACHING AND LEARNING METHOD IN TEACHING SPEAKING,” vol. 1, 2017.

25 Muslainy Muslainy, "Upaya Meningkatkan Kemampuan Menulis Developing Paragraph of Explanation Text Melalui Pendekatan Contextual Teaching and Learning (Ctl) Pada Mata Pelajaran Bahasa Inggris Siswa Kelas XII IPA 4 Sman 9 Pekanbaru," JURNAL PAJAR (Pendidikan dan Pengajaran) 1, no. 1 (n.d.): 54-59.

26 Ummu Salamah, "PENERAPAN METODE CONTEXTUAL TEACHING AND LEARNING (CTL) UNTUK MENINGKATKAN PEMAHAMAN SISWA POKOK BAHASAN 
Al Maqayís Jurnal Pendidikan Bahasa Arab dan Kebahasaaraban, 8 (2), 2021

p-ISSN 2338-133X e-ISSN 2615-3890

\section{Metdologi Penelitian}

Penelitian ini menggunakan pendekatan Kuantitatif. dengan mengumpulkan data dan menganalisisnya menggunakan rumus matematika dan statistika (Aliaga \& Gunderson, 2005); pendekatan yang digunakan untuk menguji teori-teori tertentu dengan cara meneliti hubungan antarvariabel (Creswell, 2014). Penelitian kuantitatif akan menciptakan alat ukur yang berguna untuk mengukur tingkat variabel tersebut dan menghasilkan skor. Skor tersebut kemudian akan dianalisis dan diinterpretasikan sehingga mampu menjelaskan fenomena atau variabel yang sedang diteliti. ${ }^{27}$ Peneliti menggunakan pendekatan kuantitatif untuk mengetahui efektivitas penggunaan strategi contextual teaching and learning (CTL) untuk meningkatkan keterampilan berbicara di MA Manbaul Ulum.

Metodologi penelitian yang digunakan adalah metode eksperimen. Sugiyono (2014: 72), menyatakan bahwa penelitian eksperimen adalah metode penelitian yang digunakan untuk mencari pengaruh perlakuan tertentu terhadap yang lain dalam kondisi yang terkendalikan. Jenis penelitian yang digunakan adalah desain Quasi Eksperimen. Menurut Sugiyono (2006:77), mendefinisikan bahwa : "penelitian Quasi Eksperimen adalah metode penelitian yang mempunyai kelompok kontrol tetapi tidak dapat berfungsi sepenuhnya untuk dapat mengontrol variabel-variabel luar yang mempengaruhi pelaksanaan eksperimen." 28

Rancangan penelitian yang digunakan adalah rancangan penelitian menggunakan eksperimen Non-Equivalent Control Group Design. Penelitian ini menggunakan dua kelompok, yaitu kelompok eksperimen dan kelompok kontrol. Kelas eksperimen adalah kelompok yang diberikan perlakuan penerapan strategi contextual teaching and learning

SIKLUS AIR KELAS V MADRASAH IBTIDAIYAH," EBTIDA': Jurnal Pendidikan Dasar Islam 1, no. 01 (2021): 27-35.

${ }^{27}$ Ahmad Saifuddin, “Apakah Desain Eksperimen Satu Kelompok Layak Digunakan?,” Literasi: Jurnal Kajian Keislaman Multi-Perspektif 1, no. 1 (2021): 1-22.

${ }^{28}$ Vanny Aditiany and Rani Tania Pratiwi, "PENGARUH MEDIA PEMBELAJARAN MACROMEDIA FLASH TERHADAP HASIL BELAJAR SISWA (Studi Quasi Eksperimen Pada Mata Pelajaran IPS Kelas VIII Di SMP Negeri 3 Kuningan)," Equilibrium: Jurnal Penelitian Pendidikan dan Ekonomi 18, no. 2 (2021): 102-109. 
Al Maqayís Jurnal Pendidikan Bahasa Arab dan Kebahasaaraban, 8 (2), 2021

p-ISSN 2338-133X e-ISSN 2615-3890

(CTL), sedangkan kelompok kelas kontrol adalah kelompok pengendali yaitu kelas yang tidak mendapat perlakuan atau tidak menggunakan strategi contextual teaching and learning (C'TL) ${ }^{29}$

Sugiyono (2011) mendefinisikan populasi adalah wilayah generalisasi yang terdiri atas: obyek/subyek yang mempunyai kualitas dan karakteristik tertentu yang ditetapkan oleh peneliti untuk dipelajari dan kemudian ditarik kesimpulannya. Sedangkan sampel adalah bagian dari jumlah dan karakteristik yang dimiliki oleh populasi tersebut (Sugiyono 2011). ${ }^{30}$ Adapun populasi dalam penelitian ini yaitu semua siswa kelas X di MA Manbaul Ulum.

Tabel 1: Kelompok siswa kelas X di MA Manbaul Ulum

\begin{tabular}{|c|c|c|}
\hline No & Kelas & Jumlah \\
\hline 1 & $\mathrm{XA}$ & 42 \\
\hline 2 & $\mathrm{XB}$ & 20 \\
\hline 3 & $\mathrm{XC}$ & 20 \\
\hline \multicolumn{2}{|c|}{ Total } & 82 \\
\hline
\end{tabular}

Sampel dalam penelitian ini yaitu kelas XB sebagai kelompok eksperimen yang menggunakan strategi contextual teaching and learning (CTL) untuk meningkatkan keterampilan berbicara dan kelas XC sebagai kelompok kontrol yang tidak menggunakan strategi contextual teaching and learning (CTL) untuk meningkatkan keterampilan berbicara.

${ }^{29}$ Suharsimi Arikunto, Prosedur Penelitian suatu Pendekatan Praktik(Jakarta: Ardi Mahasatya,2010) h. 354

${ }^{30}$ Herry Wira Wibawa, Hendry Muhammad Ali, and Atik Budi Paryanti, "A Analisis Faktor Faktor Yang Mempengaruhi Pendapatan UMKM," Journal of Information System, Applied, Management, Accounting and Research 5, no. 3 (2021): 650-660. 
Al Maqayis Jurnal Pendidikan Bahasa Arab dan Kebahasaaraban, 8 (2), 2021 p-ISSN 2338-133X e-ISSN 2615-3890

\section{Tahapan Penelitian}

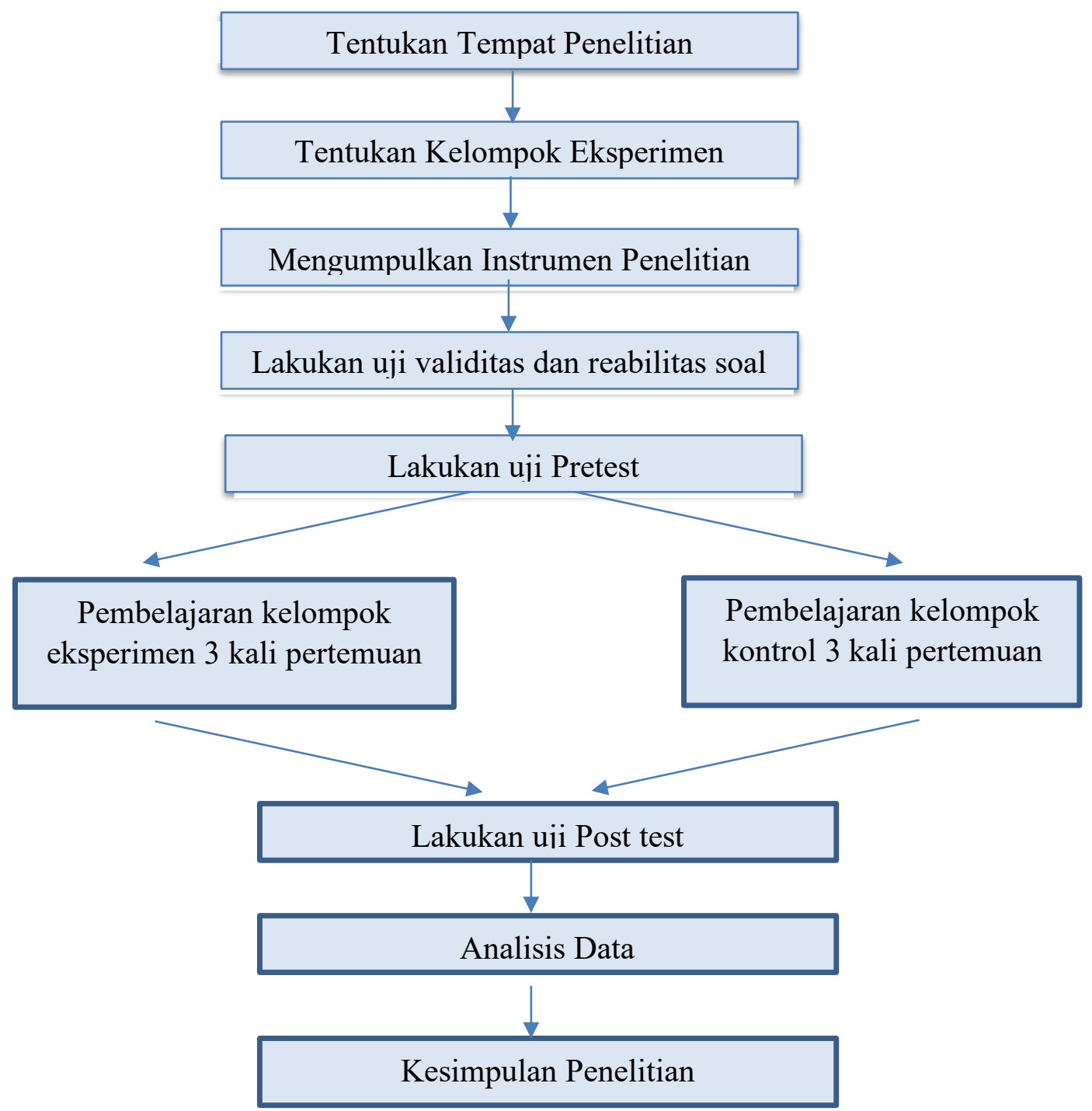


Al Maqayis Jurnal Pendidikan Bahasa Arab dan Kebahasaaraban, 8 (2), 2021

p-ISSN 2338-133X e-ISSN 2615-3890

\section{Hasil Penelitian}

Data pretest siswa untuk kelompok eksperimen dan kontrol seperti pada lampiran. Adapun langkah-langkah analisis data, untuk mengetahui nilai tertinggi, nilai terendah, rata-rata dan simpangan baku (standar deviasi). Gambaran umum hasil pretest pada dua kelompok seperti pada tabel.

Tabel 2: hasil pretest kelompok eksperimen dan kelompok kotrol

\begin{tabular}{|c|c|c|}
\hline Keterangan & Kelompok eksperimen & Kelompok Kontrol \\
\hline Nilai tertinggi & 87,5 & 81,5 \\
\hline Nilai Terendah & 56,5 & 53,5 \\
\hline Rata-rata & 73,175 & 69,3 \\
\hline $\begin{array}{c}\text { Simpangan Baku (Standar } \\
\text { Deviasi) }\end{array}$ & 9,720 & 8,278 \\
\hline
\end{tabular}

Berdasarkan tabel tersebut, rata-rata hasil kedua kelompok, terdapat perbedaan jika dilihat dari hasil saja. Pretest bertujuan untuk mengetahui kemampuan awal siswa dalam keterampilan berbicara. Namun untuk memperjelas data, peneliti menggunakan beberapa uji sebagai berikut:

Pertama uji normalitas. Uji normalitas untuk menilai sebaran data pada sebuah kelompok data atau variabel, apakah sebaran data tersebut berdistribusi normal ataukah tidak.. Peneliti menggunakan uji normalitas Kolmogorov-Smirnov dengan langkahlangkah analisis seperti pada lampiran.

Tabel 3: Hasil Analisis uji normalitas pretest

\begin{tabular}{|c|c|c|c|c|}
\hline \multirow{2}{*}{ Kelompok } & \multicolumn{2}{|c|}{ Kolmogrov- Smirnov } & \multirow{2}{*}{$\alpha$} & Kesimpulan \\
\cline { 2 - 4 } & Sampel & $\begin{array}{c}\text { Asymp. Sig. (2- } \\
\text { tailed) }\end{array}$ & 0,05 & Distribusi normal \\
\hline Eksperimen & 20 & 0,200 & 0,05 & Distribusi normal \\
\hline Kontrol & 20 & 0,200 & 0 \\
\hline
\end{tabular}


Al Maqayis Jurnal Pendidikan Bahasa Arab dan Kebahasaaraban, 8 (2), 2021 p-ISSN 2338-133X e-ISSN 2615-3890

Berdasarkan analisis data, jika Asymp. Sig. (2-tailed) > 0,05 maka data berdistribusi normal. Jika Asymp. Sig. (2-tailed) < 0,05 maka data berdistibusi tidak normal, dengan signifikansi $0,05 .^{31}$

Tabel menunjukkan kelompok eksperimen Asymp. Sig. (2-tailed) yaitu 0,200 > 0,05 sehingga data berdistibusi normal dan kelompok kontrol Asymp. Sig. (2-tailed) yaitu $0,200>0,05$ sehingga data juga berdistibusi normal.

Kedua uji homogenitas. Diketahui bahwa data pada kelompok eksperimen dan kelompok kontrol berdistribusi normal, selanjutnya peneliti akan menguji homogenitasnya. Uji homogenitas digunakan untuk mengetahui apakah beberapa varian populasi adalah sama atau tidak.. Adapun langkah-langkah analisis seperti pada lampiran.

Tabel 4: Hasil Analisis uji homogenitas pretest

\begin{tabular}{|c|c|c|c|c|}
\hline Kelompok & Sampel & $\begin{array}{c}\text { Asymp. Sig. (2- } \\
\text { tailed) }\end{array}$ & $\alpha$ & Kesimpulan \\
\cline { 1 - 2 } Eksperimen & 20 & \multirow{2}{*}{0,569} & 0,05 & Homogen \\
\hline Kontrol & 20 & Homogen \\
\hline
\end{tabular}

Berdasarkan analisis data, jika Asymp. Sig. (2-tailed) > 0,05 maka data homogen. Jika Asymp. Sig. (2-tailed) < 0,05 maka data tidak homogen, dengan signifikansi 0,05. ${ }^{32}$ Tabel menunjukkan kelompok eksperimen dan kelompok kontrol Asymp. Sig. (2-tailed) yaitu 0,569>0,05 sehingga data dari kedua kelompok homogen.

Peneliti melakukan posttest pada pertemuan keempat untuk mengetahui keberhasilan kelompok eksperimen dan kelompok kontrol dan mengetahuai apakah ada perbedaan antara kelompok eksperimen yang menggunakan strategi contextual teaching and learning (CTL) untuk meningkatkan keterampilan berbicara dan kelompok kontrol yang yang tidak menggunakan strategi contextual teaching and learning (CTL) untuk meningkatkan keterampilan berbicara.

${ }^{31}$ V. Wiratna Sujarweni, SPSS Untuk Penelitian, (Yogyakarta: Pustaka Baru Press, 2014), h. 55.

${ }^{32}$ Ibid, h. 55 
Al Maqayis Jurnal Pendidikan Bahasa Arab dan Kebahasaaraban, 8 (2), 2021

p-ISSN 2338-133X e-ISSN 2615-3890

Data posttest siswa untuk kelompok eksperimen dan kontrol seperti pada lampiran. Langkah-langkah analisis data untuk mengetahui nilai tertinggi, nilai terendah, rata-rata dan simpangan baku (standar deviasi). Gambaran umum hasil posttest pada dua kelompok seperti pada tabel.

Tabel 5: hasil posttest kelompok eksperimen dan kelompok kotrol

\begin{tabular}{|c|c|c|}
\hline Keterangan & Kelompok eksperimen & Kelompok Kontrol \\
\hline Nilai tertinggi & 97 & 90,5 \\
\hline Nilai Terendah & 70 & 55,5 \\
\hline Rata-rata & 85,075 & 77 \\
\hline $\begin{array}{c}\text { Simpangan Baku (Standar } \\
\text { Deviasi) }\end{array}$ & 8,083 & 10,850 \\
\hline
\end{tabular}

Berdasarkan tabel tersebut, rata-rata hasil kedua kelompok, terdapat perbedaan jika dilihat dari hasil saja. Posttest bertujuan untuk mengetahui pengaruh antara antara kelompok eksperimen yang menggunakan strategi contextual teaching and learning (CTL) untuk meningkatkan keterampilan berbicara dan kelompok kontrol yang yang tidak menggunakan strategi contextual teaching and learning (CTL) . Namun untuk memperjelas data, peneliti menggunakan beberapa uji sebagai berikut:

Pertama uji normalitas. Uji normalitas untuk menilai sebaran data pada sebuah kelompok data atau variabel, apakah sebaran data tersebut berdistribusi normal ataukah tidak.. Peneliti menggunakan uji normalitas Kolmogorov-Smirnov dengan langkahlangkah analisis seperti pada lampiran.

Tabel 6: Hasil Analisis uji normalitas posttest

\begin{tabular}{|c|c|c|c|c|}
\hline \multirow{2}{*}{ Kelompok } & \multicolumn{2}{|c|}{ Kolmogrov- Smirnov } & \multirow{2}{*}{$\alpha$} & Kesimpulan \\
\cline { 2 - 3 } & Sampel & $\begin{array}{c}\text { Asymp. Sig. (2- } \\
\text { tailed) }\end{array}$ & & \\
\hline Eksperimen & 20 & 0,200 & 0,05 & Distribusi normal \\
\hline Kontrol & 20 & 0,200 & 0,05 & Distribusi normal \\
\hline
\end{tabular}


Al Maqayis Jurnal Pendidikan Bahasa Arab dan Kebahasaaraban, 8 (2), 2021 p-ISSN 2338-133X e-ISSN 2615-3890

Berdasarkan analisis data, jika Asymp. Sig. (2-tailed) > 0,05 maka data berdistribusi normal. Jika Asymp. Sig. (2-tailed) < 0,05 maka data berdistibusi tidak normal, dengan signifikansi $0,05 .^{33}$

Tabel menunjukkan kelompok eksperimen Asymp. Sig. (2-tailed) yaitu 0,200 > 0,05 sehingga data berdistibusi normal dan kelompok kontrol Asymp. Sig. (2-tailed) yaitu $0,200>0,05$ sehingga data juga berdistibusi normal.

Kedua uji homogenitas. Diketahui bahwa data pada kelompok eksperimen dan kelompok kontrol berdistribusi normal, selanjutnya peneliti akan menguji homogenitasnya. Uji homogenitas digunakan untuk mengetahui apakah beberapa varian populasi adalah sama atau tidak.. Adapun langkah-langkah analisis seperti pada lampiran.

Tabel 7: Hasil Analisis uji homogenitas posttest

\begin{tabular}{|c|c|c|c|c|}
\hline Kelompok & Sampel & $\begin{array}{l}\text { Asymp. Sig. (2- } \\
\text { tailed) }\end{array}$ & $\alpha$ & Kesimpulan \\
\hline Eksperimen & 20 & \multirow[b]{2}{*}{0,135} & \multirow[b]{2}{*}{0,05} & Homogen \\
\hline Kontrol & 20 & & & Homogen \\
\hline
\end{tabular}

Berdasarkan analisis data, jika Asymp. Sig. (2-tailed) > 0,05 maka data homogen. Jika Asymp. Sig. (2-tailed) < 0,05 maka data tidak homogen, dengan signifikansi 0,05. ${ }^{34}$

Tabel menunjukkan kelompok eksperimen dan kelompok kontrol Asymp. Sig. (2-tailed) yaitu 0,,135>0,05 sehingga data dari kedua kelompok homogen.

Ketiga uji t, diketahui bahwa data dari pretest pada kelompok eksperimen dan kontrol berdistribusi normal dan homogen. Selanjutnya peneliti melakukan uji t untuk mengetahui apakah ada perbedaan kemampuan siswa antara kelompok eksperimen dan kontrol sebelum menggunakan strategi contextual teaching and learning (CTL).

Tabel 8: Hasil Analisis uji t pretest kelompok eksperimen dan kelompok kontrol

\begin{tabular}{|c|c|c|c|c|}
\hline Kelompok & Sampel & $\begin{array}{c}\text { Asymp. Sig. (2- } \\
\text { tailed) }\end{array}$ & $\alpha$ & Kesimpulan \\
\hline
\end{tabular}

${ }^{33}$ V. Wiratna Sujarweni, SPSS Untuk Penelitian, (Yogyakarta: Pustaka Baru Press, 2014 ), h. 55.

${ }^{34}$ Ibid, h. 55 
Al Maqayis Jurnal Pendidikan Bahasa Arab dan Kebahasaaraban, 8 (2), 2021

p-ISSN 2338-133X e-ISSN 2615-3890

\begin{tabular}{|c|l|l|l|l|}
\hline Eksperimen & 20 & \multirow{2}{*}{0,183} & 0,05 & $\begin{array}{c}\mathrm{H}_{\mathrm{a}} \text { ditolak dan } \\
\mathrm{H}_{0} \text { diterima }\end{array}$ \\
\hline Kontrol & 20 & 0,18 \\
\hline
\end{tabular}

$\mathrm{H}_{\mathrm{a}}$ : Terdapat perbedaan kemampuan siswa antara kelompok eksperimen dan kontrol sebelum menggunakan strategi contextual teaching and learning (CTL).

$\mathrm{H}_{0}$ : Tidak ada perbedaan kemampuan siswa antara kelompok eksperimen dan kontrol sebelum menggunakan strategi contextual teaching and learning (CTL).

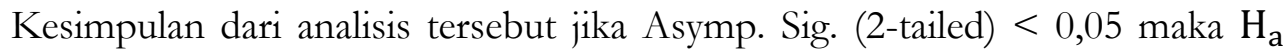
diterima dan $\mathrm{H}_{0}$ ditolak.dan jika Asymp. Sig. (2-tailed) > 0,05 maka $\mathrm{H}_{\mathrm{a}}$ ditolak dan $\mathrm{H}_{0}$ diterima dengan signifikansi $0,05.35$

Berdasarkan perhitungan pada lampiran diketahui hasil Asymp. Sig. (2-tailed) $0,183>0,05$ maka $\mathrm{H}_{\mathrm{a}}$ ditolak dan $\mathrm{H}_{0}$ diterima. Kesimpulan dari hasil analisis yaitu tidak ada perbedaan kemampuan siswa antara kelompok eksperimen dan kontrol sebelum menggunakan strategi contextual teaching and learning (CTL), atau kemampuan awal kelompok eksperimen dan kontrol adalah sama.

Data dari posttest pada kelompok eksperimen dan kontrol berdistribusi normal dan homogen. Selanjutnya peneliti melakukan uji t untuk mengetahui apakah ada perbedaan antara kelompok eksperimen yang menggunakan strategi contextual teaching and learning (CTL) dan kelompok kontrol yang tidak menggunakan strategi contextual teaching and learning (CTL) berdasarkan pada hasil posttest.

Tabel 9: Hasil Analisis uji t posttest kelompok eksperimen dan kontrol

\begin{tabular}{|c|c|c|c|c|}
\hline Kelompok & Sampel & $\begin{array}{c}\text { Asymp. Sig. (2- } \\
\text { tailed) }\end{array}$ & $\alpha$ & Kesimpulan \\
\cline { 1 - 2 } Eksperimen & 20 & \multirow{2}{*}{0,011} & 0,05 & $\begin{array}{c}\mathrm{H}_{\mathrm{a}} \text { diterima dan } \\
\mathrm{H}_{0} \text { ditolak }\end{array}$ \\
\hline Kontrol & 20 & 0,011 \\
\hline
\end{tabular}

$\mathrm{H}_{\mathrm{a}}$ : Terdapat perbedaan hasil antara kelompok eksperimen yang menggunakan strategi contextual teaching and learning (CTL) dan kelompok kontrol yang tidak

35 Ibid, h.99 


\section{Al Maqayis Jurnal Pendidikan Bahasa Arab dan Kebahasaaraban, 8 (2), 2021 \\ p-ISSN 2338-133X e-ISSN 2615-3890}

menggunakan strategi contextual teaching and learning (CTL) untuk mningkatkan keterampilan berbicara di MA Manbaul Ulum.

$\mathrm{H}_{0}$ : Tidak ada perbedaan hasil antara kelompok eksperimen yang menggunakan strategi contextual teaching and learning (CTL) dan kelompok kontrol yang tidak menggunakan strategi contextual teaching and learning (CTL) untuk mningkatkan keterampilan berbicara di MA Manbaul Ulum.

Kesimpulan dari analisis tersebut jika Asymp. Sig. (2-tailed) $<0,05$ maka $_{\mathrm{a}}$ diterima dan $\mathrm{H}_{0}$ ditolak.dan jika Asymp. Sig. (2-tailed) $>0,05$ maka $\mathrm{H}_{\mathrm{a}}$ ditolak dan $\mathrm{H}_{0}$ diterima dengan signifikansi 0,05. ${ }^{36}$

Berdasarkan perhitungan pada lampiran diketahui hasil Asymp. Sig. (2-tailed) $0,011<0,05$ maka $\mathrm{H}_{\mathrm{a}}$ diterima dan $\mathrm{H}_{0}$ ditolak. Kesimpulan dari hasil analisis yaitu terdapat perbedaan hasil antara kelompok eksperimen yang menggunakan strategi contextual teaching and learning (CTL) dan kelompok kontrol yang tidak menggunakan strategi contextual teaching and learning (CTL) untuk meningkatkan keterampilan berbicara di MA Manbaul Ulum.

Maka disimpulkan strategi contextual teaching and learning (CTL) efektif untuk meningkatkan keterampilan berbicara siswa kelas X di MA Manbaul Ulum.

\section{Kesimpulan}

Beberapa kesimpulan berdasarkan penelitian, yaitu : (1) Gambaran Pembelajaran keterampilan berbicara di MA Manbaul Ulum yaitu guru meminta siswa melafalkan bacaan dan percakapan di buku dan meminta anak menjawab soal dari buku satu persatu. Kemudian guru meminta siswa menerjemahkan kalimat yang dibacanya dari buku dan guru membantu dalam menerjemahkan kosa kata bahasa Arab. (2) Hasil Pretest antara kelompok eksperimen dan kontrol pada uji t diperoleh Asymp. Sig. (2tailed) $0,183>0,05$ maka tidak ada perbedaan kemampuan siswa antara kelompok eksperimen dan kontrol sebelum menggunakan strategi contextual teaching and learning (CTL), atau kemampuan awal kelompok eksperimen dan kontrol adalah sama. Serta

36 Ibid, h.99 
Al Maqayis Jurnal Pendidikan Bahasa Arab dan Kebahasaaraban, 8 (2), 2021

p-ISSN 2338-133X e-ISSN 2615-3890

hasil posttest antara kelompok eksperimen dan kelompok kontrol pada uji t diperoleh Asymp. Sig. (2-tailed) 0,011 < 0,05 maka terdapat perbedaan hasil antara kelompok eksperimen yang menggunakan strategi contextual teaching and learning (CTL) dan kelompok kontrol yang tidak menggunakan strategi contextual teaching and learning (CTL) untuk meningkatkan keterampilan berbicara di MA Manbaul Ulum. Oleh karena itu, penggunaan strategi contextual teaching and learning (CTL) untuk meningkatkan keterampilan berbicara di MA Manbaul Ulum dikatakan efektif.

\section{Daftar Pustaka}

Aditiany, Vanny, and Rani Tania Pratiwi. "PENGARUH MEDIA PEMBELAJARAN MACROMEDIA FLASH TERHADAP HASIL BELAJAR SISWA (Studi Quasi Eksperimen Pada Mata Pelajaran IPS Kelas VIII Di SMP Negeri 3 Kuningan).” Equilibrium: Jurnal Penelitian Pendidikan dan Ekonomi 18, no. 2 (2021): 102-109.

Bandung, Murti. “THE EFFECTIVENESS OF CONTEXTUAL TEACHING AND LEARNING METHOD IN TEACHING SPEAKING.” Vol. 1, 2017.

Erni, Erawati, Muhammad Yunus, and Muhammad Nur. "Pengaruh Model Pembelajaran Contextual Teaching Learning (CTL) Terhadap Hasil Belajar IPS Siswa SD." Bosowa Journal of Education 1, no. 1 (2020): 16-23.

Fadhilah, S Ag. "Penerapan Metode Contextual Teaching Learning Dalam Pembelajaran Ilmu Nahu Di MAN 2 Bireuen" (n.d.).

Gatra, I Made. "Meningkatkan Keterampilan Berbicara Siswa SMA Dwijendra Gianyar Melalui Model Pembelajaran Contextual Teaching And Learning." Journal of Education Action Research 2, no. 4 (2018): 322-330.

Gunawan, Adi, Hariyono Hariyono, and Ari Sapto. "Perbedaan Hasil Belajar Ilmu Pengetahuan Sosial Dengan Pendekatan Kontekstual Berbasis Budaya Lokal Di Madura." Jurnal Pendidikan: Teori, Penelitian, dan Pengembangan 2, no. 6 (2017): 867873.

Haslinda, Haslinda. "KONSTRUKSI PENDEKATAN PEMBELAJARAN KONTEKSTUAL (CONTEXSTUAL TEACHING AND LEARNING) 
Al Maqayis Jurnal Pendidikan Bahasa Arab dan Kebahasaaraban, 8 (2), 2021 p-ISSN 2338-133X e-ISSN 2615-3890

\section{DALAM PENGAJARAN BAHASA (SUATU TINJAUAN EVALUASI)."} Vol. 1, 2018.

Hidayati, Sri. "Strategi Pembelajaran Anak Usia Dini” (2021).

Husnawati, Anita, Siti Fatima Azis, Hajira Burui, Sri Wahyuningsi Laiya, and Waode Eti Hardiyanti. "Strategi Pembelajaran Anak Usia Dini Pada Masa Pandemi Covid19." 29-36, 2021.

Imelda, Imelda, Gazali Gazali, and Efendi Efendi. "Meningkatkan Keterampilan Berbicara Siswa Kelas VI SD Inpres Kantewu Melalui Pendekatan Contextual Teaching And Learning (CTL)." Jurnal Kreatif Online 6, no. 2 (n.d.).

Kasuma, I Putu Adi, MG Rini Kristiantari, and Ni Nyoman Ganing. "PENGARUH PENDEKATAN CONTEXTUAL TEACHING AND LEARNING (CTL) TERHADAP HASIL BELAJAR BAHASA INDONESIA SISWA.” MIMBAR PGSD Undiksha 5, no. 2 (2017).

Kurnia, Putu Intan. "Meningkatkan Keterampilan Berbicara Menggunakan Metode Contextual Teaching and Learning Siswa Kelas XI SMK BSI." Jurnal Ilmu Sosial, Manajemen, Akuntansi dan Bisnis 1, no. 1 (2020): 14-23.

Lestari, Nyoman Ayu Putri. "Pengaruh Implementasi Pembelajaran Kontekstual Terhadap Hasil Belajar Matematika Dengan Kovariabel Kemampuan Numerik Dan Kemampuan Verbal." Jurnal Pendidikan Dasar Nusantara 5, no. 1 (2019): 72 87.

Maja, Andika. "Peningkatan Keterampilan Berbicara Siswa Menggunakan Pendekatan Pembelajaran Kontekstual Berbantuan Media Gambar Di Sekolah Dasar." Jurnal Pendidikan dan Pembelajaran Khatulistiwa 6, no. 3 (n.d.).

Malmia, Wa, Jumi Latbual, Vivi R Hentihu, and Siti Hajar Loilatu. "Efektifitas Pembelajaran Contextual Teaching and Learning (Ctl) Terhadap Hasil Belajar Matematika Siswa:(The Effectiveness of Contextual Teaching and Learning (Ctl) on Student Mathematics Learning Achievements)." Uniqbu Journal of Exact Sciences 1, no. 2 (2020): 31-39.

Muslainy, Muslainy. "Upaya Meningkatkan Kemampuan Menulis Developing Paragraph of Explanation Text Melalui Pendekatan Contextual Teaching and Learning (Ctl) Pada Mata Pelajaran Bahasa Inggris Siswa Kelas XII IPA 4 Sman 9 Pekanbaru." JURNAL PAJAR (Pendidikan dan Pengajaran) 1, no. 1 (n.d.): 54 59.

Mustofa, Saiful. “تأثثير استخدام وسيلة التعليم" لعبة دمية الأصابع" لترقية مهارة الكلام." Arabia 9, no. 2 (2019). 
Al Maqayis Jurnal Pendidikan Bahasa Arab dan Kebahasaaraban, 8 (2), 2021 p-ISSN 2338-133X e-ISSN 2615-3890

Nasirudin, Ahmad, Intan Rahmawati, and Suyitno Suyitno. "KEEFEKTIFAN MODEL CONTEXTUAL TEACHING AND LEARNING (CTL) TERHADAP HASIL BELAJAR MATEMATIKA MATERI PECAHAN." Journal for Lesson and Learning Studies 2, no. 2 (2019): 150-159.

Nurhayati, Tati, Rini Herminastiti, and Nor Khakim. "Upaya Meningkatkan Keterampilan Berbicara Melalui Metode Contextual Teaching and Learning Dalam Kegiatan Circle Time,” 2019.

Parwasih, Ni Wayan Sri, and Zusje WM Warouw. "Pengaruh Model Pembelajaran Contextual Teaching and Learning (CTL) Terhadap Hasil Belajar Siswa Pada Pembelajaran IPA Materi Sistem Pencernaan Manusia." SCIENING: Science Learning Journal 1, no. 1 (2020): 6-10.

Saifuddin, Ahmad. "Apakah Desain Eksperimen Satu Kelompok Layak Digunakan?” Literasi: Jurnal Kajian Keislaman Multi-Perspektif 1, no. 1 (2021): 1-22.

Salamah, Ummu. "PENERAPAN METODE CONTEXTUAL TEACHING AND LEARNING (CTL) UNTUK MENINGKATKAN PEMAHAMAN SISWA POKOK BAHASAN SIKLUS AIR KELAS V MADRASAH IBTIDAIYAH.” EBTIDA': Jurnal Pendidikan Dasar Islam 1, no. 01 (2021): 27-35.

Sardi, Maulana Ismail, Imran Akhmad, and Sanusi Hasibuan. "PERBEDAAN STRATEGI PEMBELAJARAN TERHADAP MOTIVASI DAN HASIL BELAJAR PASSING ATAS BOLA VOLI PADA SISWA KELAS XI SMA.” Jurnal Pedagogik Olahraga 7, no. 1 (n.d.): 19-24.

Septian, Damar, Ifa Fauziyah Farid, Selamet Syaifuddin, and Sri Hastuti. "Respon Dan Pengaruh Pendekatan Contextual Teaching Learning Terhadap Hasil Belajar IPA Materi Perubahan Sifat Benda Pada Siswa Kelas V Sekolah Dasar." Jurnal Pendidikan Fisika dan Sains (JPFS) 4, no. 1 (2021): 32-38.

SEPTYA, RAHAYU. "PENERAPAN PENDEKATAN CONTEXTUAL TEACHING AND LEARNING (CTL) DALAM PEMBELAJARAN TEMATIK KELAS 1 SD NEGERI 02 MERGAWATI, KECAMATAN KROYA CILACAP” (2021).

Siregar, Ziaulhaq. "PENINGKATAN KEMAMPUAN PEMECAHAN MASALAH DAN SIKAP POSITIF MATEMATIS SISWA SMP NEGERI 4 PANTAI LABUMELALUI PENDEKATAN KONTEKSTUAL” (2018).

Wati, Sakdiah. "KEEFEKTIFAN PENDEKATAN KONTEKSTUAL (CONTEXTUAL TEACHING AND LEARNING) DALAM PEMBELAJARAN MENULIS PUISI SISWA SMP.” Jurnal Bindo Sastra 3, no. 1 (2019): 55-62. 
Al Maqayís Jurnal Pendidikan Bahasa Arab dan Kebahasaaraban, 8 (2), 2021 p-ISSN 2338-133X e-ISSN 2615-3890

Wibawa, Herry Wira, Hendry Muhammad Ali, and Atik Budi Paryanti. "A Analisis Faktor Faktor Yang Mempengaruhi Pendapatan UMKM." Journal of Information System, Applied, Management, Accounting and Research 5, no. 3 (2021): 650-660.

Yogiswari, Ni Putu, Ni Ketut Suarni, and I Wayan Suastra. "Pengaruh Pendekatan Pembelajaran Kontekstual Berbasis Multiple Intelligences Gardner Terhadap Minat Dan Hasil Belajar IPA." Jurnal Pendidikan dan Pembelajaran IP A Indonesia 9, no. 3 (2019): 112-121. 